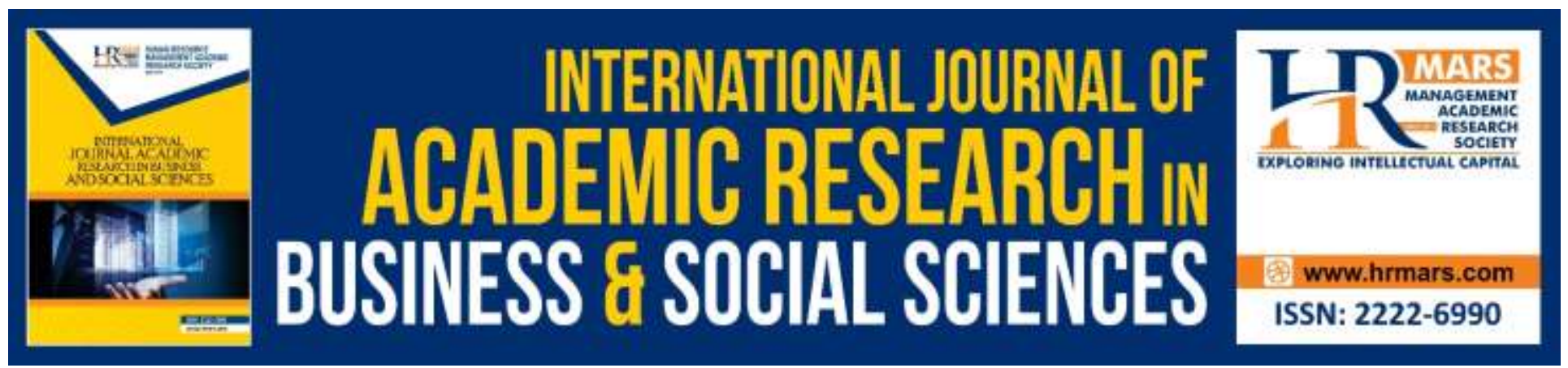

\title{
The Development of Higher Order Thinking Skills (HOTS) Assessment Instrument for Word Problems
}

\section{Fadzli Ali Karim and Marzita Puteh}

To Link this Article: http://dx.doi.org/10.6007/IJARBSS/v9-i6/6069

DOI: $10.6007 /$ IJARBSS/v9-i6/6069

Received: 08 April 2019, Revised: 17 May 2019, Accepted: 04 June 2019

Published Online: 29 June 2019

In-Text Citation: (Karim \& Puteh, 2019)

To Cite this Article: Karim, F. A., \& Puteh, M. (2019). The Development of Higher Order Thinking Skills (HOTS) Assessment Instrument for Word Problems. International Journal of Academic Research in Business and Social Sciences, 9(6), 1079-1083.

Copyright: (C) 2019 The Author(s)

Published by Human Resource Management Academic Research Society (www.hrmars.com) This article is published under the Creative Commons Attribution (CC BY 4.0) license. Anyone may reproduce, distribute, translate and create derivative works of this article (for both commercial and non-commercial purposes), subject to full attribution to the original publication and authors. The full terms of this license may be seen at: http://creativecommons.org/licences/by/4.0/legalcode

Vol. 9, No. 6, 2019, Pg. $1079-1083$

Full Terms \& Conditions of access and use can be found at http://hrmars.com/index.php/pages/detail/publication-ethics 


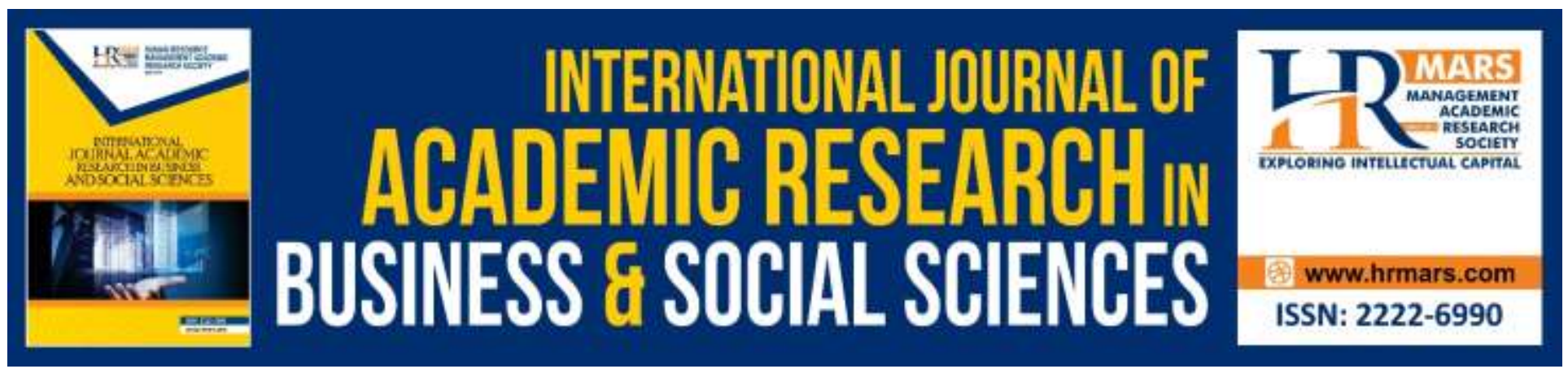

\title{
The Development of Higher Order Thinking Skills (HOTS) Assessment Instrument for Word Problems
}

\author{
Fadzli Ali Karim ${ }^{1}$ and Marzita Puteh ${ }^{2}$ \\ Faculty of Science and Mathematics Sultan Idris Education University, 35900, Tanjong Malim, Perak, \\ Malaysia
}

\begin{abstract}
This study aims to test the validity and reliability of a Primary School Assessment Instrument for Year 4 students which cover the topic length involving word problems. This research is a developmental research. The product of this research is to develop instruments in subjective test items. The validation of assessment instrument is carried out to evaluate the validity of the assessment instrument. The validation is performed in the early stages of product development by three experts on Mathematics Education. The findings show that all experts agree that the content and quality of the item. The Cohen kappa value is 0.75 . The finding indicates that the instrument has a high validity. A total of 20 Year 4 students from a rural primary school in the District of Marudi, Baram, Sarawak were involved in this study. From the analysis, it was found that the Cronbach alpha coefficient value is 0.857 . This finding shows that the instrument has a high reliability coefficient.
\end{abstract}

Keywords: Assessment, Higher Order Thinking Skills (HOTS), Instrument, Word Problems, Validity, Reliability

\section{Introduction}

Primary education is the key towards the successful of an education system in. The mathematical curriculum has been designed to enable all students to acquire the skills, knowledge and values in mathematical education (Kementerian Pelajaran Malaysia, 1988).

Transformation in the state education system has started in 2011 with the implementation of the Primary School Standard Curriculum (KSSR) to replace the Integrated Curriculum (KBSR).

The Malaysian Education Development Plan (PPPM) 2013 - 2025 has been planned to face the 21st century challenges. Within 13 years, various strategies and plans have been planned to improve the quality and standard of Malaysia education. The first wave of the Malaysian Education Development Plan (2013 - 2015) has emphasized on the re-examination of questions so that it is more 
geared towards higher-order thinking skills questions (Malaysia Education Blueprint, 2013). Higher order thinking skills (HOTS) is one of the important aspects in teaching learning. With the ability of higher order thinking skills, students are able to understand the concept of mathematics well and apply in everyday life.

\section{Research Background}

The Mathematics Education is gradually challenging with the emergence of higher order thinking skill questions in UPSR. Higher order thinking skills questions are being expanded and all students need to master these skills (Ministry of Education Malaysia, 2012). For teachers and rural school students, it is an aspect that needs to be emphasized. Teachers need to embrace various new methods as outlined in the 21st century education. In order to empower students especially in responding to the higher order thinking skills questions, teachers need to route the learning process and facilitate the best possible ways. In Mathematics education, it is important for the teacher to explain the situation based on the students' skills.

Bloom's Taxonomy has greatly influenced teaching and learning processes and assessments in the Malaysian education system and is still emphasized in mathematical education, especially in the areas of higher order thinking skills. According to Bloom's taxonomy, there are six levels of student thought starting with a low level to a higher level; knowledge, understanding, application, analysis, synthesis and evaluation. For the mathematical problem solving questions, a great emphasis is given on the students' ability to think at high levels (Nordin, 2013).

The ability of the students in answering HOTS mathematics questions has not reached the minimum level (Azrul et al., 2017). This is inclined with the TIMSS results which indicated that Malaysia students are still at the low international benchmark (TIMSS, 2015). One of the factors is students in Malaysia are lacks of practice involving problem solving which measures HOTS. On the other hand, teachers are lack of ability to develop the HOTS assessment instrument (Silverman \&Thompson, 2008). The lacking and the unavailability of the assessment instrument designed specifically to practice HOTS is the major problem (Mazlini \& Marzita, 2018). Therefore, it is important to develop HOTS assessment instruments, especially for primary school.

Hence, with the development of this Higher Order Thinking Skills Assessment test items for primary school students, we will be well informed on the students' HOTS ability and thus, pedagogical steps can easily be taken by teachers to nourish them.

\section{Research Methodology}

This research is a developmental research. The main objective of this research is to (1) develop a Mathematics Higher Order Thinking Skills Assessment instrument for Year Four students, (2) test the validity and reliability of the instrument that has been developed.

The process in this development stage includes the preparation of test items. The test items consist of 10 word problem questions which cover the topic length Year 4 . The test items were designed based on Bloom's Taxonomy domains. For each domain, there are break down of two 
INTERNATIONAL JOURNAL OF ACADEMIC RESEARCH IN BUSINESS AND SOCIAL SCIENCES

Vol. 9, No. 6, June, 2019, E-ISSN: 2222-6990 @ 2019 HRMARS

questions. Pupils are allocated one hour to answer the questions which are aligned with the time allocated in Mathematics Paper 2, UPSR.

The test item that has been designed has been assessed by the three experts. Then, revision was done based on the experts' reviews and comments. Pilot test has been conducted to group of student to determine the quality of the test items.

\section{Findings and Discussion}

\section{Instrument Validity Result}

The validation is performed in the early stage of the assessment instrument development. Three experts from Mathematics Education Department were involved to assess the validity of the assessment instrument. The findings show that all experts agree that the content and quality of the item. The Cohen kappa value is $\mathbf{0 . 7 5}$. The finding indicates that the instrument has a high validity.

\section{Instrument Reliability}

The empirical test of HOTS mathematics test item was done by conducting a pilot test. A total of 20 Year 4 students from a rural primary school in the District of Marudi, Baram, Sarawak were involved in this study. Students were allocated 1 hour to answer the questions.

Table 1: Reliability Statistics

\begin{tabular}{|r|r|}
\hline $\begin{array}{c}\text { Cronbach's } \\
\text { Alpha }\end{array}$ & N of Items \\
\hline .857 & 20 \\
\hline
\end{tabular}

From the analysis, it was found that the Cronbach alpha coefficient value is 0.857 . This shows that the assessment instrument for word problem involving the topic length has a high reliability coefficient.

\section{Conclusion}

In conclusion, the instrument validity and reliability is an effort to measure whether the test items suit the target group. Through this study, it is found that the instrument has 10 subjective word problem questions. For each questions, there is a breakdown of two questions. These questions were developed with reference to the Year 4 Mathematics DSKP as well as the Year 4 text book.

\section{Corresponding Author}

Marzita Puteh

Falculty of Science and Mathematics

Sultan Idris Education University, 35900 Tanjong Malim

Perak, Malaysia, Email: marzita@fsmt.upsi.edu.my 
INTERNATIONAL JOURNAL OF ACADEMIC RESEARCH IN BUSINESS AND SOCIAL SCIENCES

Vol. 9, No. 6, June, 2019, E-ISSN: 2222-6990 (C) 2019 HRMARS

\section{References}

Nordin, A. B. (2013). Kurikulum Ke arah Penghasilan Kemahiran Berfikir Kritis, Kreatif dan Inovatif. Jurnal Kurikulum dan Pengajaran Asia Pasifik, 1, 10-18

Aziz, Azrul, A.M. A., Puteh, M., Tajudin, N. M., \& Mazlini, A. (2017). Pupils Achievement Towards Higher Order Thinking Skill Mathematics Questions With Bar Model Method. Sci. Int. (Lahore), 29(4), 733-73

Kementerian Pelajaran Malaysia (2010). Dokumen Standard. Kurikulum Standard Sekolah Rendah. Bahagian Pembangunan Kurikulum

Kementerian Pelajaran Malaysia (1988). Falsafah Pendidikan Kebangsaan. Kuala

Lumpur; Pusat Perkembangan Kurikulum

Adnan, M. \& Puteh, M. (2018). Developing a Secondary Mathematics Higher Order Thinking Skills Assessment (SMHOTSA) Instrument. 8. 1238-1246. 10.7456/1080SSE/166.

Ministry of Education Malaysia. (2012).Kemahiran Berfikir Aras Tinggi dalam Sains dan Matematik (HOTsSM).Putrajaya:

Malaysia Education Blueprint. (2013). Malaysia Education Blueprint 2013 - 2025. Education, 27(1), 1268. https://doi.org/10.1016/j.tate.2010.08.007

TIMSS. (2015). TIMSS 2015 International Results in Mathematics. Retrieved from http://timssandpirls.bc.edu/timss2015/

Silverman, J. \& Thompson, P., Towards. (2008). A framework for the development of mathematical knowledge for teaching, Journal of Mathematics Teacher Education, 11(6), $499-511$. 